\begin{tabular}{cc|c}
\hline Tar. Bil. Der. & Journal of Agricultural Sciences \\
& $\begin{array}{c}\text { Dergi web sayfası: } \\
\text { www.agri.ankara.edu.tr/dergi }\end{array}$ & Journal homepage: \\
& www.agri.ankara.edu.tr/journal
\end{tabular}

\title{
Farklı Tuzluluk Düzeylerinin Sarımsakta (Allium sativum L.) Verim ve Bazı Kalite Özelliklerine Etkisi
}

\author{
Ahmet TURHAN ${ }^{a}$, Hayrettin KUŞÇU ${ }^{\mathrm{a}}$, Neşe ÖZMEN ${ }^{\mathrm{b}}$, Ali Osman DEMIIR \\ ${ }^{a}$ Uludağ Üniversitesi, Mustafakemalpaşa Meslek Yüksekokulu, Bitkisel ve Hayvansal Üretim Bölümü, 16500, Bursa, TÜRKiYE \\ ${ }^{b}$ Uludağ Üniversitesi, Mustafakemalpaşa Meslek Yüksekokulu, Gıda İsleme Bölümü, 16500 Bursa, TÜRKIYE \\ ${ }^{c}$ Uludağ Üniversitesi Ziraat Fakültesi, Biyosistem Mühendisliği Bölümü, 16059, Görükle, Bursa, TÜRKIYE
}

\section{ESER BİLGISII}

Araştırma Makalesi DOI: 10.1501/Tarimbil_0000001287

Sorumlu Yazar: Ahmet TURHAN, E-posta: turhan@uludag.edu.tr, Tel: +90 (224) 6133102

Geliş Tarihi: 11 Aralık 2013, Düzeltmelerin Gelişi: 31 Ocak 2014, Kabul: 19 Şubat 2014

\section{ÖZET}

Bu çalışmada, Balıkesir sarımsağı üzerine farklı tuz dozlarının (1.60, 2.87, 4.14, 5.41, 6.68 ve $\left.7.95 \mathrm{dS} \mathrm{m}^{-1}\right)$ etkisi, verim ile toplam kuru madde, suda çözünür kuru madde, toplam şeker, toplam asit, vitamin $\mathrm{C}$ ve protein gibi bazı kalite özellikleri belirlenerek değerlendirilmiştir. Deneme tesadüf parselleri deneme desenine göre 6 yinelemeli olarak sera koşullarında yürütülmüştür. Sonuçlar, farklı tuz uygulamalarının baş verimi ve kalitesi üzerine istatistikî olarak önemli etkisi olduğunu göstermiştir. Baş verimi, toplam şeker ve asit içerikleri $2.87 \mathrm{dS} \mathrm{m}^{-1}$ 'ye kadar artış gösterirken, en yüksek suda çözünür kuru madde ve protein içeriği $4.14 \mathrm{dS} \mathrm{m}^{-1}$ ' de elde edilmiş, söz konusu düzeylerin üzerindeki tuzluluk seviyelerinde değerler azalmıştır. Benzer biçimde, toplam kuru madde miktarı $4.14 \mathrm{dS} \mathrm{m}^{-1}$ 'ye kadar toprak tuzluluğundan etkilenmemiş ancak bu düzeyden sonra önemli ölçüde azalmıştır. Ayrıca, tuzluluktaki artışla Vitamin C içeriği azalmıştır. Çalışma sonuçlarına göre, $4.14 \mathrm{dS} \mathrm{m}^{-1}$ 'ye kadar toprak tuzluluğunda yeterli düzeyde kaliteli ve verimli sarımsak yetiştirilebileceği belirlenmiştir.

Anahtar Kelimeler: Toprak tuzluluğu; Sarımsak (Allium sativum L.); Tuz stresi; Meyve kalitesi

\section{The Effect of Different Salinity Levels on the Yield and Some Quality Parameters of Garlic (Allium sativum L.)}

\author{
ARTICLE INFO \\ Research Article \\ Corresponding Author: Ahmet TURHAN, E-mail: turhan@uludag.edu.tr, Tel: +90 (224) 6133102 \\ Received: 11 December2013, Received in Revised Form: 31 January 2014, Accepted: 19 February 2014
}

\begin{abstract}
In this study, the effect of different salinity levels $\left(1.60,2.87,4.14,5.41,6.68\right.$ and $\left.7.95 \mathrm{dS} \mathrm{m}^{-1}\right)$ on Balıkesir garlic was evaluated by the determination of yield and quality parameters such as total dry matter, total soluble solids, total sugar, total acid, vitamin $\mathrm{C}$ and protein. The experiment was conducted incompletely randomized design with six replicates under greenhouse conditions. The results revealed that different treatments of salinity had statistically considerable
\end{abstract}


effects on the bulb yield and quality. The values of the bulb yield, total sugar and acid contents were increased up to $2.87 \mathrm{dS} \mathrm{m}^{-1}$ while the soluble solids and protein gave the highest values at $4.14 \mathrm{dS} \mathrm{m}^{-1}$. Furthermore, their values were decreased with increasing salinity of above mentioned levels. Similarly, the amount of total dry matter was unaffected by soil salinity up to $4.14 \mathrm{dS} \mathrm{m}^{-1}$, but decreased significantly after this level. Increasing salt concentrations also decreased the values of vitamin $\mathrm{C}$. The results of this study revealed that, considering the yield and quality, garlic can be grown satisfactorily under the condition of soil salinity up to $4.14 \mathrm{dS} \mathrm{m}^{-1}$.

Keywords: Soil salinity; Garlic (Allium sativum L.); Salt stress; Fruit quality

(C) Ankara Üniversitesi Ziraat Fakültesi

\section{Giriş}

Kültür bitkilerinde tuz stresine neden olan tuzlu topraklar, dünyada geniş alanlar kaplamaktadır (Uno et al 1996). Toprak tuzluluğu, tarımsal üretimi sınırlandıran önemli etmenlerden biridir (Szabolcs 1994) ve yüksek düzeyde ekonomik kayılara neden olmaktadır (Mahajan \& Tuteja 2005). Tuz stresi, bitki büyüme ve gelişmesini dolayısı ile verimliliğini olumsuz yönde etkilemektedir (Zahra et al 2010). Bununla birlikte, söz konusu olumsuz etkiler, bitki türlerine göre değişim göstermektedir (Torech \& Thompson 1993).

Sarımsak ülkemizin her tarafında yetiştirilen ve çevre şartlarına iyi adapte olabilen bir sebzedir (Vural et al 2000). Türkiye, sarımsak üretiminde söz sahibi ülkeler arasında olup dünya sarımsak üretimi içerisinde yaklaşık \% 4'lük pay ile yedinci sırada yer almaktadir (Taban et al 2004; Ipek et al 2008). Türkiye'de 2012 yılı tarım istatistik verilerine göre 79433 ton/yıl sarımsak üretilmektedir. Maas \& Hofmann (1977) göre, sarımsak tuzluluğa orta derecede duyarlı ve diğer birçok sebzeye göre tuza toleransı biraz daha yüksektir. Toprak tuzluluğunun $3.9 \mathrm{dS} \mathrm{m}^{-1}$ ve üzerine çıktığı koşullarda verim azalmaya başlamakta ve tuzluluk $7.4 \mathrm{dS} \mathrm{m}^{-1}$ 'ye ulaştığında tüm verim bileşenlerindeki (toplam verim, baş ağırlığ 1 ve çapı) azalma \% 50’ye kadar ulaşmaktadır. Düşük tuz konsantrasyonlarında verim azalması, bireysel baş ağırlığındaki düşüşler ile gerçekleşmektedir. Yüksek tuz konsantrasyonlarında ise verimdeki azalmada daha çok birim alandaki baş sayısının azalması rol oynamaktadır (Francois 1994). Tuzluluk, sarımsak veriminde olduğu gibi kalite özellikleri üzerinde de önemli düzeyde değişimlere neden olmaktadır.
Suda çözünür kuru madde, baş kalitesinde en önemli parametredir (Shannon \& Grieve 1999). Francois (1994) artan tuz konsantrasyonlarının suda çözünür kuru madde miktarını önemli ölçüde düşürdüğünü, $4.2 \mathrm{dS} \mathrm{m}^{-1}$ ye kadar kuru madde miktarının arttığını ve bu konsantrasyondan sonra artan tuzluluk ile birlikte kuru madde miktarının azaldığını bildirmiştir.

Tuzlu koşullar altında yetiştirilen sarımsaklarda meydana gelen verim ve kalite değişimleri konusunda yapılan çalışmalar oldukça sınırlıdır (Francois 1994). Bu araştırmada; ülkemizde yetiştirilen Balıkesir sarımsağına değişik tuzluluk stres seviyeleri uygulanmış, uygulanan tuz stresi ve sarımsak baş verimi ile kalite parametreleri (toplam kuru madde, suda çözünür kuru madde, toplam şeker, toplam asit, vitamin $\mathrm{C}$ ve protein) arasındaki ilişkilerin ortaya konulması amaçlanmıştır.

\section{Materyal ve Yöntem}

Araştırma, 2013 yılında Uludağ Üniversitesi Mustafakemalpaşa Meslek Yüksekokuluna ait plastik örtülü uygulama serası ve gıda laboratuarında yürütülmüştür.

Denemede, Balıkesir ilinden sağlanan yerel sarımsak (Allium sativum L.) materyal olarak kullanılmıştır.

Araştırmada, saksı kültürü yetiştirme tekniği kullanılmıştır. Bu amaçla, $30 \mathrm{~cm}$ çaplı ve $40 \mathrm{~cm}$ derinliği olan siyah renkli plastik saksılardan yararlanılmıştır. Saksıların içerisine konulmak üzere getirilen topraklar (Mustafakemalpaşa Meslek Yüksekokuluna ait uygulama arazisinin üst $30 \mathrm{~cm}$ derinliğinden kazılarak alınan), 4 
mm göz açıklıklı elekten elendikten sonra hava kurusu duruma gelinceye kadar kurutulmuştur. $\mathrm{Bu}$ topraklara ait bazı fiziksel ve kimyasal özellikler Çizelge 1'de verilmiştir. Denemede ele alınan toprakların tuzluluk düzeylerinin oluşturulmasında, üç farklı $\mathrm{NaCl}, \mathrm{CaCl}_{2}, \mathrm{MgSO}_{4}$ tuzları kullanılmıştır. Üç farklı tuzun (ağırlık esasına göre 1:1:1 karışımı) değişen miktarlarının toprak örneklerine ilavesi ile $1.60,2.87,4.14,5.41,6.68$ ve $7.95 \mathrm{dS} \mathrm{m}^{-1}$ EC değerleri oluşturulmuştur. Elektriksel iletkenlik, Ayyıldız (1990) tarafından belirtilen esaslara göre, saturasyon eriyiğinde elektriksel iletkenlik aleti (TDScan-4 model, Eutech Inst. Singapore) ile belirlenmiştir.

Araştırma, 6 tekerrürlü tesadüf parselleri deneme desenine uygun olarak yürütülmüştür. Her tekerrürde 3 adet plastik saksı ve her saksıda da 2 adet sarımsak bitkisi olacak şekilde düzenleme yapılmıştır.

Deneme desenine uygun olarak sera içerisine yerleştirilen saksılara polietilen torba geçirilmiş ve içersine farklı tuzluluk düzeylerinde hazırlanmış $30 \mathrm{~kg}$ toprak konulmuştur. Saksılara temel gübre olarak, üre formunda $10.8 \mathrm{mg} \mathrm{kg}^{-1}$ $\mathrm{N}$ ve triple süperfosfat formunda $15.2 \mathrm{mg} \mathrm{kg}^{-1}$ $\mathrm{P}_{2} \mathrm{O}_{5}$ uygulanmıştır (Mirzaei et al 2007). Azotlu gübrenin yarısı dikimden önce diğer yarısı da bitki baş bağlamaya geçtiğinde verilmiştir. Fosforlu gübrenin tamamı ise dikimden önce uygulanmıştır. Toprakta yeterli miktarda potasyum bulunduğu için potasyumlu gübreleme yapılmamıştır. Homojen iriliğe sahip sarımsak dişleri; Şubat ayı başında, her saksıya 2 adet olmak üzere ve Vural et al (2000) tarafından belirtildiği gibi dişlerin uç kısımları toprak yüzeyinde görülecek biçimde dikilmiştir. Ekim yapıldıktan sonra saksılardaki toprağın nemi, saf su ile tarla kapasitesi seviyesine çıkarılmıştır. Ayrıca deneme süresince, toprağın nemi saf su ile tarla kapasitesinde tutulan nemin \% 75'i olacak şekilde sulama yapılmıştır. Bitkilere gerekli bakım işlemleri düzenli olarak yapılmıştır. Yetiştirme süresi boyunca sera ortamındaki ortalama sicaklık ve nem, sırasıyla $22^{\circ} \mathrm{C}$ ve $\% 70$ olarak ölçülmüştür.
Çizelge 1- Denemede kullanılan toprakların bazı fiziksel ve kimyasal özellikleri

Table 1-Some physical and chemical properties of soils used in the study

\begin{tabular}{ll}
\hline Bünye sınıfi & Killi tın \\
\hline Tarla kapasitesi (\%) & 30.0 \\
Hacim ağırlığ $\left(\mathrm{g} \mathrm{cm}^{-3}\right)$ & 1.4 \\
$\mathrm{pH}$ & 7.9 \\
Elektriksel iletkenlik (EC, dS m-1) & 0.49 \\
Kireç $\left(\mathrm{CaCO}_{3}, \%\right)$ & 11.9 \\
Organik Madde (\%) & 2.0 \\
Toplam $\mathrm{N}(\%)$ & 0.17 \\
Alınabilir $\mathrm{P}_{2} \mathrm{O}_{5}\left(\mathrm{mg} \mathrm{kg}^{-1}\right)$ & 11.8 \\
Alınabilir $\mathrm{K}_{2} \mathrm{O}\left(\mathrm{mg} \mathrm{kg}^{-1}\right)$ & 283 \\
Alınabilir $\mathrm{Ca}\left(\mathrm{m} \mathrm{kg}^{-1}\right)$ & 4139 \\
Alınabilir $\mathrm{Mg}\left(\mathrm{mg} \mathrm{kg}^{-1}\right)$ & 557 \\
Alınabilir Fe $\left(\mathrm{mg} \mathrm{kg}^{-1}\right)$ & 7.7 \\
Alınabilir $\mathrm{Mn}\left(\mathrm{mg} \mathrm{kg}^{-1}\right)$ & 7.0 \\
Alınabilir $\mathrm{Zn}\left(\mathrm{mg} \mathrm{kg}^{-1}\right)$ & 0.83 \\
Alınabilir $\mathrm{Cu}\left(\mathrm{mg} \mathrm{kg}^{-1}\right)$ & 2.23 \\
Koordinat & $40^{\circ} 02^{\prime} \mathrm{N}, 28^{\circ} 23^{\prime} \mathrm{E}$ \\
\hline
\end{tabular}

Hasat, bitkinin yapraklarının kurumaya başladığ 1 Haziran ayı ortalarında yapılmıştır. Topraktan çıkartılan bitkiler, plastik örtü üzerinde 2 hafta kadar güneş görmeyen gölge bir yerde kurumaya bırakılmıştır (Francois 1994). Kurutma sonrasında bitkiler kök, baş ve yaprak kısımlarına ayrılmıştır. Sarımsak başları tartılarak baş verimi $\left(\mathrm{g}\right.$ baş $\left.{ }^{-1}\right)$ bulunmuştur.

Analizler için, hasat edilen tüm başlarda bulunan dişler çeşme suyu ile temizlenerek saf sudan geçirilmiş ve blenderde öğütülmüştür. Alınan örnekler, $70{ }^{\circ} \mathrm{C}$ sıcaklıkta 2 gün boyunca etüvde kurutulmuş ve tartılarak toplam kuru madde miktarı (\%) saptanmıştır (Francois 1994). Suda çözünebilir kuru madde ( ${ }^{\circ}$ Briks), refraktometre (Abbe-type refractometer, model 60/Direct Reading, Bellington \& Stanley Inc., Kent, UK) ile doğrudan meyve suyu kullanılarak yapılmıştır (Tigchelaar 1986). Toplam asitlik (\%) ise aynı meyve suyunun $0.1 \mathrm{~N}$ $\mathrm{NaOH}$ ile titrasyonu sonucu belirlenmiştir (NCARL 1968). Şeker analizleri için Luff-Schoorl yöntemi kullanılmış ve sarımsak örneklerindeki toplam 
şeker miktarı \% olarak hesaplanmıştır (Gormley \& Maher 1990). Vitamin C (askorbik asit) sarımsak örneklerinde titrasyon metodu ile $\mathrm{mg} 100 \mathrm{~g}^{-1}$ olarak belirlenmiştir (AOAC 1980). Protein tayini için, öncelikle örneklerde toplam azot Kjeldahl yöntemi ile belirlenmiş ve bulunan toplam azot 6.25 faktörü ile çarpılarak protein miktarı \% olarak hesaplanmıştır (AOAC 1980).

Sarımsaklarda baş verimi, toplam kuru madde ve suda çözünür kuru madde miktarı, toplam şeker, toplam asit, vitamin $\mathrm{C}$ ve protein içeriğine ilişkin değerler istatistikî olarak varyans analizi ile değerlendirmeye tabi tutulmuş ve ortalamalar arasındaki farklılıklar LSD testi ile saptanmıştır. İstatistikî analizlerde MINITAB 14 ve MSTAT-C paket programları kullanılmıştır (Steel \&Torrie 1980). Ayrıca, tuzluluk stres seviyesi ile baş verimi ve kalite özellikleri arasındaki ilişkiler regresyon analizleri ile değerlendirilmiştir. İlişkilerin doğrusal veya doğrusal olmayan bir fonksiyonla açıklanmasında en küçük kareler yöntemi kullanılmıştır (Alma \& Vupa 2008).

\section{Bulgular ve Tartışma}

Toprak tuzluluğu, kültür bitkilerinde büyüme ve verimi sınırlandıran önemli faktörlerden birisidir (Al-Maskri et al 2010; Francois \& Maas 1994; Rouphael et al 2006; Tzortzakis 2009). Mensah et al (2006) yüksek tuzluluğun bitkilerde verim azalmasına neden olduğunu bildirmişlerdir. Yapılan bu çalışma ile birlikte, sarımsak baş veriminin $2.87 \mathrm{dS} \mathrm{m}^{-1}$ 'ye kadar artış gösterdiği ve bu seviyenin üzerinde artan tuz stresinde baş verimlerinde istatistikî olarak önemli miktarda verim kayıplarına neden olduğu belirlenmiştir. Buna göre, tuzluluk ile baş verimi arasında 3 . dereceden polinom biçiminde bir ilişki elde edilmiştir (Şekil 1). Francis (1994) sarımsaklarda yaptığı benzer bir çalışmada, düşük tuzluluğun baş verimini etkilemediğini, $3.9 \mathrm{dS} \mathrm{m}^{-1}$ üzerinde artan tuzlulukla birlikte baş veriminin önemli miktarda azaldığını tespit etmiştir. Şekil 1'de işaretçilerin yanındaki değerler, sırasıyla 1.60, 2.87, 4.14, 5.41, 6.68 ve $7.95 \mathrm{dS} \mathrm{m}^{-1}$ toprağın elektriksel iletkenliğinden elde edilen baş verimleridir.
*, F testine göre $\mathrm{P}<0.05$ düzeyinde önemlidir. Aynı grafik içerisinde aynı harfle gösterilen değerler \% 5 olasılık düzeyinde istatistiksel olarak önemsizdir.

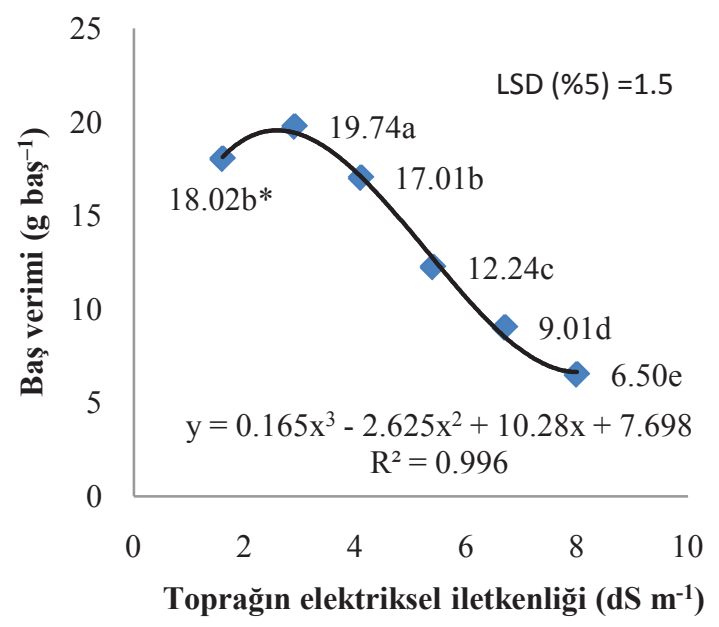

Şekil 1- Toprağın elektriksel iletkenliğinin baş verimi üzerine etkisi

Figure 1- Effect of electrical conductivity of soil on bulb yield

Tuzluluk, bitki kalite parametrelerini genellikle olumsuz olarak etkilemektedir (Shannon \& Grieve 1999). Bu yargıya benzer olarak, yüksek tuzluluk düzeylerinde sarımsağın baş kalite parametreleri, genelde olumsuz olarak etkilenmiştir. Uygulanan tuz stresi ile baş kalite özellikleri arasında önemli regresyon eşitlikleri elde edilmiştir (Şekil 2). Şekil 2'de işaretçilerin yanındaki değerler, sırasıyla $1.60,2.87,4.14,5.41,6.68$ ve $7.95 \mathrm{dS} \mathrm{m}^{-1}$ toprağın elektriksel iletkenliğine tepkisidir. *, F testine göre $\mathrm{P}<0.05$ düzeyinde önemlidir. Aynı grafik içerisinde aynı harfle gösterilen değerler $\% 5$ olasılık düzeyinde istatistiksel olarak önemsizdir. Özellikle toplam kuru madde ve suda çözünür kuru madde, sarımsak baş kalitesinin belirlenmesinde önemli etmenlerdir (Francois 1994; Gvozdanovic-Varga et al 2004). Düşük tuzluluk stresinin $(1.60,2.87$ ve $4.14 \mathrm{dS}$ $\mathrm{m}^{-1}$ ) uygulandığ 1 bitkilerin toplam kuru madde miktarlarında istatistikî açıdan önemli farklılık bulunmamıştır. Buna karşın, $4.14 \mathrm{dS} \mathrm{m}^{-1}$ üzerinde uygulanan tuz streslerinin, toplam kuru madde miktarını önemli ölçüde azalttığı saptanmıştır. Diğer 
taraftan, suda çözünür kuru madde miktarları 4.14 $\mathrm{dS} \mathrm{m}^{-1}$ tuzluluk seviyesine kadar artış göstermiş ve bu noktadan sonra artan tuz stresinin etkisiyle önemli miktarda azalmıştır. Buna göre, tuzluluk stresi ve toplam kuru madde arasinda 2.dereceden polinom, tuz seviyesi ve suda çözünür kuru madde arasında ise 3.dereceden polinom biçiminde önemli ilişkiler belirlenmiştir (Şekil 2). En düşük toplam kuru madde ve suda çözünür kuru madde miktarları, $7.95 \mathrm{dS} \mathrm{m}^{-1}$ lik en yüksek tuz stresi uygulamasıyla elde edilmiştir. Bu çalışmadan elde edilen bulgulara paralel olarak, Francois (1994) yüksek tuz stresinin sarımsakta suda çözünür kuru madde miktarını düşürdügünü belirlemiştir. Ayrıca, yüksek tuz stresi marul ve ispanak bitkilerinde de toplam kuru madde miktarlarını önemli ölçüde azalttığı daha önce yapılan çalışmalarda raporlanmıştır (Miceliet al 2003; Mekki \& Orabi 2007; Al-Maskri et al 2010; El-Abagy et al 2012; Turhan et al 2013).

Toplam şeker ve asit içerikleri kalitenin belirlenmesinde önemli rol oynamaktadır (Moretti et al 1998). Bu çalışmada, sarımsak başlarından alınan örneklerde yapılan analizler sonucunda, uygulanan tuz stres seviyeleri ile başların toplam şeker ve asit içerikleri arasında istatistikî olarak önemli ilişkiler olduğu belirlenmiştir (Şekil 2). En yüksek toplam şeker $2.87 \mathrm{dS} \mathrm{m}^{-1}$ uygulamasında bulunurken, artan tuz stresiyle birlikte şeker içeriği de önemli miktarda azalma göstermiş ve 7.95 $\mathrm{dS} \mathrm{m}^{-1}$ uygulamasında \% 1.61 seviyesine kadar düşmüştür. Şeker içeriğinde olduğu gibi toplam asit içeriklerinde de benzer ilişkiler olduğu Şekil 2'den görülebilmektedir. En yüksek toplam asit 2.87 $\mathrm{dS} \mathrm{m}^{-1}$ uygulamasinda bulunurken, bu seviyenin üzerinde artarak devam eden tuz stresi toplam asit içeriklerinde yüksek miktarda azalmalara neden olmuştur. Bu çalışmada, sarımsak başlarından elde edilen en düşük toplam asit ise 6.68 ve $7.95 \mathrm{dS} \mathrm{m}^{-1}$ uygulamalarından elde edilmiştir. Amuthavalli et al (2012), pamuk (Gossypium hirsutum L.) bitkisinde tuzlulukla $(\mathrm{NaCl})$ birlikte toplam şeker içeriğinin azaldığını raporlamışlardır. Ayrıca, çilek bitkisine (Fragaria $\times$ ananassa Duch.) uygulanan tuz stresindeki artışın, daha düşük şeker içeriği, organik asit ve suda çözünür kuru madde miktarına bağlı olarak meyve kalitesini düşürdüğü bildirilmiştir (Keutgen \& Pawelzik 2007).

Vitamin C (askorbik asit) önemli bir antioksidandır. Askorbik asit, bitkilerde büyüme düzenleyici olarak rol oynamakta (Garg \& Kapoor 1972; Conklin 2001) ve tuzun zararlı etkilerini azaltmaktadır (Shalata \& Neumann 2001). Bu araştırmada, tuz stresindeki artışa bağlı olarak Vitamin C içeriği azalmıştır. Yapılan regresyon analizi sonucunda, toprağın elektriksel iletkenliği ile Vitamin C içeriği arasında istatistikî açıdan önemli negatif doğrusal bir ilişki belirlenmiştir (Şekil 2). En yükssek Vitamin C içeriği, $1.60 \mathrm{dS} \mathrm{m}^{-1}$

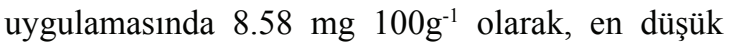
Vitamin C içeriği ise $7.95 \mathrm{dS} \mathrm{m}^{-1}$ uygulamasında 6.57 mg $100 \mathrm{~g}^{-1}$ olarak bulunmuştur. Pitura \& Michalojc (2012) yüksek toprak tuzluluğunun marul (Lactuca sativa) ve kereviz (Apium graveolens) bitkilerinde azot düzeyini artırması nedeniyle vitamin $\mathrm{C}$ içeriğini azalttığını belirlemişlerdir.

Farklı tuz stresi uygulanmış sarımsak başlarının protein içerikleri arasında istatistikî açıdan önemli farklılıkların olduğu Şekil 2'den de görülebilmektedir. Tuz ilavesiyle toprağın elektriksel iletkenliğindeki artış, öncelikle protein içeriklerinin artmasına sebep olmuş ve en yüksek değer $4.14 \mathrm{dS} \mathrm{m}^{-1}$ uygulamasında \% 7.83 olarak belirlenmiştir. Bu bulguya benzer olarak, Mansur et al (2000) tuz stresinin protein birikimini arttırdığını bildirmişlerdir. Buna karşın, $4.14 \mathrm{dS} \mathrm{m}^{-1}$ üzerinde artarak devam eden toprak tuzluluğu protein içeriklerini önemli miktarda azaltmıştır. Sarımsak bitkilerine uygulanan en yüksek tuzluluk seviyesi olan $7.95 \mathrm{dS} \mathrm{m}^{-1}$ 'de ise protein içeriği \% 4.47'ye kadar düşmüştür.

\section{Sonuçlar}

Baş verimi sarımsak bitkisi için önemli parametrelerden biridir. Verimdeki azalmalar üretici gelirine yansımakta ve gelir kayıplarına neden olmaktadır. Bu çalışma ile birlikte verimde azalma olmaksızın sarımsak yetiştirilebilecek topraklardaki tuzluluğun $2.87 \mathrm{dS} \mathrm{m}^{-1}$ ye kadar çıkabileceği, fakat $2.87 \mathrm{dS} \mathrm{m}^{-1}$ üzerinde artan toprak tuzluluğunun baş 

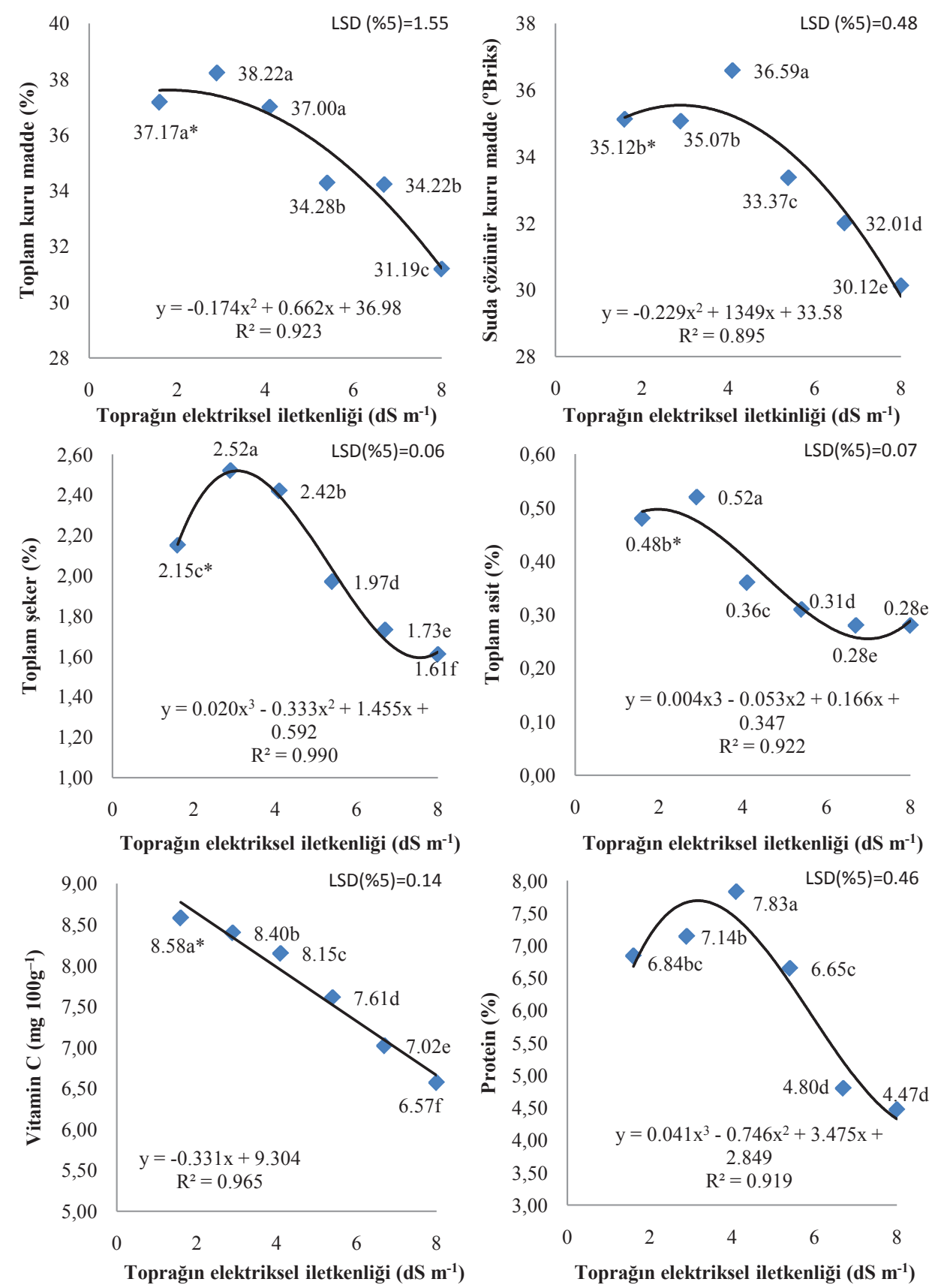

Şekil 2- Toprağın elektriksel iletkenliğinin sarımsak başlarında toplam kuru madde, suda çözünür kuru madde, toplam şeker, toplam asit, vitamin $C$ ve protein içeriği üzerine etkileri

Figure 2- Effects of electrical conductivity of soil on total dry matter, soluble solids, total sugar, total acidity, vitamin $C$, and protein content of garlic bulb 
verimini önemli ölçüde azaltacağı saptanmıştır. Tüketici tercihi ve gıda işleme sanayisi tarafindan bakıldığında ise kalite ön plana çıkmaktadır. Özellikle etkili kök bölgesi tuzluluk seviyesinin $4.14 \mathrm{dS} \mathrm{m}^{-1}$ 'ye kadar artması, sarımsak bitkisinin toplam kuru madde, suda çözünür kuru madde, toplam şeker, toplam asit ve protein gibi önde gelen kalite parametrelerini olumlu olarak etkilediği belirlenmiştir. Bununla birlikte $4.14 \mathrm{dS} \mathrm{m}^{-1}$ üzerinde artan tuzluluğun ise kalite parametrelerinde önemli miktarda kayıplar meydana getirebileceği ortaya konmuştur. Artan tuz konsantrasyonlarının vitamin C içeriğini önemli miktarda azalttığı yapılan tespitlerden biridir. Sonuç olarak, $4.14 \mathrm{dS} \mathrm{m} \mathrm{m}^{-1}$ düzeyine kadar toprak tuzluluğu koşullarında kabul edilebilir sınırlar içinde kaliteli ve verimli sarımsak yetiştiriciliği yapılabilir.

\section{Kaynaklar}

Al-Maskri A, Al-Kharusi L \& Al-Miqbali H (2010). Effects of salinity stress on growth of lettuce (Lactuca sativa) under closed-recycle nutrient film technique. International Journal of Agricultural Biology 12: 377-380

Alma G M \& Vupa H (2008). Regresyon analizinde kullanılan en küçük kareler ve en küçük medyan kareler yöntemlerinin karşılaştırılması. SD ̈̈ Fen Edebiyat Fakültesi Fen Dergisi (E-dergi) 3(2): 219229

Amuthavalli A, Anbu D \& Sivasankatamoorthy S (2012). Effect of calcium chloride on growth and biochemical constituents of cotton (Gossypium hirsutum L.) under salt stress. International Journal of Research in Botany 2(3): 9-12

AOAC (1980). Official Methods of Analysis. 13 $3^{\text {th }}$ Ed., Association of Official Analytical Chemists, Washington, DC

Ayyıldız M (1990). Sulama Suyu Kalitesi ve Tuzluluk Problemleri. Ankara Üniversitesi Ziraat Fakültesi Yayınlart: 1196, Ders kitab1: 344, Ankara

El-Abagy H M, Yonma I H, Omar N M, El-Gradly N H M \& El-Tohamy W A (2012). Comparative study on the effect of some nutritional fertilizers on growth and yield of lettuce plants. Journal Applied Sciences Research 8(2): 896-900
Francois L E (1994). Yield and quality response of salt stressed Garlic. Hortscience 29(11): 1314-1317

Francois L E \& Maas E V (1994). Crop response and management of salt affected soils, in: Pessarakli M (Ed.), Handbook of Plant and Crop Stress, Marcel Dekker, New York, pp. 449-459

Garg O P \& Kapoor V (1972). Retardation of leaf senescence by ascorbic acid. Journal of Experimental Botany 23(76): 699-703

Gormley T R \& Maher M J (1990). Tomato fruit quality-an interdisciplinary approach. Professional Horticulture 4: 7-12

Gvozdanovic-Varga J, Vasic J M, Cervenski J \& Bugarski D (2004). Genotype and environment effects on yields and quality winter garlic. Genetika 36(2): 161-170

Ipek M, Ipek A \& Simon P W (2008). Molecular characterization of Kastamonu garlic: An economically important garlic clone in Turkey. Scientia Horticulturae 115(2): 203-208

Keutgen A \& Pawelzik E (2007). Modification of tasterelevant compounds in strawberry fruit under $\mathrm{NaCl}$ salinity. Food Chemistry 105: 1487-1494

Maas E V \& Hoffman G J (1977). Crop salt tolerancecurrent assessment. Journal of the Irrigation and Drainage Division 103: 115-119

Mahajan S \& Tuteja N (2005). Cold, Salinity and Drought stresses: An overview. Biochemistry and Biophysics 444: $139-158$

Mensah J K, Akomeah P A, Ikhajiagbe B \& Ekpekurede E O (2006). Effects of salinity on germination, growth and yield of five ground nut genotypes. African Journal of Biotechnology 5(20): 1973-1979

Mansour M M, Van Hasselt P R \& Kuiper P J (2000). $\mathrm{NaCl}$ effects on root plasma membrane ATPase of salt-tolerant wheat. Biologia Plantarum 43: 61-66

Miceli A, Moncada A \& D'Anna F (2003). Effect of salt stress in lettuce cultivation. Acta Horticulturae 609: 371-375

Mekki B B \& Orabi S A (2007). Response of prickly lettuce to uniconazole and irrigation with diluted seawater. American-Eurasian Journal of Agricultural \& Environmental Sciences 2(6): 611-618

Mirzaei R, Liaghati H \& Damghani AM(2007). Evaluating yield quality and quantity of garlic as affected by different farming system and garlic clones. Pakistan Journal of Biological Sciences 10(13): 2219-2224 
Moretti C L, Sargent S A, Huber D J, Calbo A G \& Puschmann R (1998). Chemical composition and physical properties of pericarp, locule and placental tissues of tomatoes with internal bruising. Journal of the American Society for Horticultural Science 123: 656-660

NCARL (1968). National Canners Association Research Laboratory. Laboratory manual for food canners and processors ([3rd ed.]). AVI Publishing, Westport, Conn

Pitura K \& Michalojc Z (2012). Influence of nitrogen doses on salt concentration, yield, biological value, and chemical composition of some vegetables plants pieces. Part I. Yield and biological value. Acta Scientiarum Polonorum Hortorum Cultus 11(6): 145 153

Rouphael Y, Cardarelli M, Rea E, Battistelli A \& Colla $\mathrm{G}$ (2006). Comparison of the sub irrigation and dripirrigation system for greenhouse zucchini squash production using saline and non-saline nutrient solutions. Agricultural Water Management 82: 99-117

Shalata A \& Neumann P M (2001). Exogenous ascorbic acid (vitamin C) increases resistance to salt tolerance and reduced lipid peroxidation. Journal of Experimental Botany 364: 2207-2211

Shannon M C \& Grieve C M (1999). Tolerance of vegetable crops to salinity. Scienta Horticulturae 78:5-38

Steel R G D \& Torrie J H (1980). Principles and Procedures of Statistics.A Biometrical Approach. McGraw-Hill Publishers, New York

Szabolcs I (1994). Soil salinization. In: M. Pesserakli (Ed.), Handbook of Plant Crop Stress. Marcel Dekker, New York, pp. 3-11
Taban S, Çıkılı Y, Kebeci F, Taban N \& Sezer S M (2004). Taşköprü yöresinde sarımsak tarımı yapılan toprakların verimlilik durumu ve potansiyel beslenme problemlerinin ortaya konulması. Tarm Bilimleri Dergisi 10(3): 297-304

Tigchelaar E C (1986). Tomato breeding. In: M J Basset (Ed.) Breeding Vegetables Crops, Westport, USA, pp. 135-170

Torech F R \& Thompson L M (1993). Soils and soil fertility. Oxford University Press, New York

Turhan A, Kuscu H, Ozmen N, Asik B B, Serbeci M M \& Seniz V (2013). Alleviation of deleterious effects of salt stress by applications of supplementary potassium-calcium on spinach. Acta Agriculturae Scandinavica, Section B - Soil \& Plant Science 63(2): 184-192

Tzortzakis N G (2009). Alleviation of salinity-induced stress in lettuce growth by potassium sulphate using nutrient film technique. International Journal of Vegetable Science 15(3): 226-239

Uno Y, Kanechi M, Inaki N, Sugimato M \& Maekawa S (1996). Theevaluation of salt tolerance during germination and vegetative growth of asparagus, table beet and sea aster. Journal of the Japanese Society for Horticultural Science 65(3): 579-585

Vural H, Eşiyok D \& Duman İ (2000). Kültür Sebzeleri (Sebze Yetiştirme). Ege Üniversitesi Basımevi, İzmir

Zahra S, Amin B \& Mehdi Y (2010). The salicylic acid effect on the tomato (Lycopersicum esculentum Mill.) germination, growth and photosynthetic pigment under salinity stress $(\mathrm{NaCl})$. Journal of Stress Physiology and Biochemistry 6(3): 4-16 